\title{
Sources of Particulate Organic Matter across Mangrove Forests and Adjacent Ecosystems in Different Geomorphic Settings
}

\author{
Daniel A. Saavedra-Hortua ${ }^{1}$ (1) • Daniel A. Friess ${ }^{2} \cdot$ Martin Zimmer ${ }^{1,3} \cdot$ Lucy Gwen Gillis $^{1}$
}

Received: 14 October 2019 / Accepted: 16 December 2019 / Published online: 6 February 2020

(C) The Author(s) 2019

\begin{abstract}
Mangrove forests are among the world's most productive ecosystems and provide essential ecosystem services such as global climate regulation through the sequestration of carbon. A detailed understanding of the influence of drivers of ecosystem connectivity (in terms of exchange of suspended particulate organic matter), such as geomorphic setting and carbon stocks, among coastal ecosystems is important for being able to depict carbon dynamics. Here, we compared carbon stocks, $\mathrm{CO}_{2}$ fluxes at the sediment-air interface, concentrations of dissolved organic carbon and suspended particulate organic carbon across a mangrove-seagrass-tidal flat seascape. Using stable isotope signatures of carbon and nitrogen in combination with MixSIAR models, we evaluated the contribution of organic matter from different sources among the different seascape components. Generally, carbon concentration was higher as dissolved organic carbon than as suspended particulate matter. Geomorphic settings of the different locations reflected the contributions to particulate organic matter of the primary producers. For example, the biggest contributors in the riverine location were mangrove trees and terrestrial plants, while in fringing locations oceanic and macroalgal sources dominated. Anthropogenic induced changes at the coastal level (i.e. reduction of mangrove forests area) may affect carbon accumulation dynamics in adjacent coastal ecosystems.
\end{abstract}

Keywords Connectivity $\cdot$ Blue carbon $\cdot$ Carbon flux $\cdot$ Seagrass beds $\cdot$ Tidal flats $\cdot$ Suspended particulate matter

\section{Introduction}

Mangrove forests play an important role of the tropical seascape, as well as for blue carbon accumulation, as they

Daniel A. Saavedra-Hortua

daniel.hortua@leibniz-zmt.de

Daniel A. Friess

dan.friess@nus.edu.sg

Martin Zimmer

martin.zimmer@leibniz-zmt.de

Lucy Gwen Gillis

lucy.gillis@leibniz-zmt.de

1 Mangrove Ecology, Leibniz Centre for Tropical Marine Research, Fahrenheitstraße, 6, 28359 Bremen, Germany

2 Department of Geography, National University of Singapore, 1 Arts Link, Singapore 117570, Singapore

3 Faculty 02 Biology/Chemistry, University of Bremen, 28359 Bremen, Germany are sites of storage and exchange of carbon (Dittmar et al. 2012; Duarte et al. 2013; Kristensen et al. 2008). Mangrove forests store carbon within their aboveground (AGB) and belowground living biomass (BGB), nonliving biomass (e.g. dead wood) and sediments (Alongi 2014). Together with saltmarshes and seagrasses, mangrove forests are known as a "blue carbon" ecosystem, referring to the high rates at which these coastal ecosystems sequester and store carbon (Lovelock and Duarte 2019).

Multiple studies have quantified mangrove carbon stocks (Bhomia et al. 2016; Kauffman et al. 2011; Murdiyarso et al. 2015), suggesting an important role in climate regulation. Moving beyond stock assessments, studies have now started to show how carbon stocks may differ with climate (Simard et al. 2019) or geomorphic setting (Rovai et al. 2018) at regional to global scales. On a local scale, physical and bio-geographic factors (i.e. climate regime, tidal regime, geomorphology, hydrodynamics, and nutrient dynamics) influence the carbon dynamics in mangrove forests (Alongi 2014). 
Understanding the factors that influence carbon storage and estimating carbon emissions and exchange at the seascape level across physical and ecological gradients is important to understand blue carbon dynamics.

Landscape structure includes the spatial arrangement and composition of landscape elements (corridors, patches and matrix) and ecological fluxes (e.g., movements of water, nutrients, organisms and other materials), and is an important landscape ecology research topic (Wu 2012). The fluxes and exchange of organic carbon among ecosystems are particularly important in networks of coastal ecosystems that release and trap carbon and nutrient subsidies from adjacent ecosystems (Gillis et al. 2014a, 2017). Carbon stored in coastal tropical vegetated ecosystems can either be produced autochthonously, or imported from adjacent ecosystems (Adame and Lovelock 2011; Hyndes et al. 2014; Duarte et al. 2013). Carbon flow among ecosystems can occur actively by motile consumers (Bouillon and Connolly 2009) or passively by tides, coastal currents and/or river discharge transporting suspended detrital particulate carbon and dissolved organic and inorganic carbon (Hyndes et al. 2014; Bouillon et al. 2008; Gillis et al. 2014b). Several studies suggest that connectivity is important to the understanding of the ecosystem processes that underlie blue carbon sequestration (Gillis et al. 2014a; Olds et al. 2016; Walton et al. 2014; Twilley et al. 1992). However, only few studies have directly measured carbon stocks (Phang et al. 2015) or nutrient fluxes (Huxham et al. 2018) across adjacent ecosystems such as tidal flats and seagrass beds.

The aim of this study was to evaluate the relative contribution of mangrove trees, seagrass plants, macroalgae, terrestrial plants and oceanic sources (plankton and suspended particulate matter (SPM)), to the particulate organic matter (POM) pool in the coastal water body. We define SPM as all suspended matter including inorganic and organic matter, while POM only includes the organic pool of the suspended matter. In order to explore carbon stocks, $\mathrm{CO}_{2}$ and carbon exchange and the contributions of the main primary producers to POM, we chose three mangrove-seagrass/tidal flat ecotones along the coast of Singapore. Our research questions were: (1) what are the carbon stocks in the mangrove tree biomass, seagrass plants and the upper $15 \mathrm{~cm}$ of sediment, and $\mathrm{CO}_{2}$ fluxes from the sediment to the atmosphere of three mangrove forests under similar climatic conditions but different geomorphic settings (riverine vs. fringing, according to (Ewel et al. 1998)) and (2) what is the role of mangrove forests and adjacent ecosystems as donors and recipients of POM across different geomorphic settings? We hypothesized that biomass, $\mathrm{CO}_{2}$ fluxes and connectivity (through POM exchange) with adjacent ecosystems is influenced by landscape structure (i.e. mangrove forest or catchment area spatial arrangement).

\section{Materials and Methods}

\section{Sampling Design}

Three intertidal continuums in northern Singapore were selected: Sungei Buloh $\left(1^{\circ} 26^{\prime} 47^{\prime \prime} N, 103^{\circ} 43^{\prime} 25^{\prime \prime} \mathrm{E}\right)$, Seletar Island $\left(1^{\circ} 26^{\prime} 36^{\prime \prime} \mathrm{N}, 103^{\circ} 51^{\prime} 43^{\prime \prime} \mathrm{E}\right)$ and Chek Jawa $\left(1^{\circ} 24^{\prime}\right.$ $\left.39^{\prime \prime} \mathrm{N}, 103^{\circ} 59^{\prime} 26^{\prime \prime} \mathrm{E}\right)$. Those sites included two mangrove forests-tidal flat (Sungei Buloh and Seletar Island) and one mangrove forests-seagrass bed ecotones (Chek Jawa). In each location, mangrove forests were present alongside other intertidal ecosystems such as tidal flats or seagrass beds (Fig. 1). Sampling was conducted during the late Northeast Monsoon (Dry Phase) from February to March 2017. Daily averages of temperature were between 23 and $32^{\circ} \mathrm{C}$ and total daily rainfall between 0 and $31 \mathrm{~mm}$ (Meteorological service Singapore, http://www.weather.gov.sg).

Transects were set across the intertidal zone, starting at the tidal flat or seagrass bed and ending at the mangrove forestterrestrial ecotone, extending landward. Within each location we established three transects separated by a distance of 50 to $500 \mathrm{~m}$, depending on alongshore mangrove forest extent. The distance between points along each transect was determined by the total cross-shore length along the intertidal gradient of the mangrove forest, but sampling points were generally separated by 20 to $120 \mathrm{~m}$, to gain a representation of the entire forest width.

Sungei Buloh and Chek Jawa had between three to five points on each transect, whilst Seletar Island had two points on each transect; terrestrial sampling points were not possible here due to impenetrable forest cover. Terrestrial points at Sungei Buloh did not follow a line but were taken at the closest point possible to the last mangrove-terrestrial forest ecotone. Terrestrial sampling was not possible at Seletar due to impenetrable forest cover. Transect points inside the mangrove that were closest to the ocean are defined as mangrove forest 1 (MF1), and the three points furthest from the ocean as mangrove forest 3 (MF3). For seagrass beds, the three transect points furthest from the mangrove forest are defined as seagrass bed 1 (SB1), and the three closest to the mangrove forest as seagrass bed 3 (SB3). The tidal flat transect point was classified with (TF), and the terrestrial area with (TE).

\section{Biomass Carbon Estimation}

At each transect point inside the mangrove forest, a plot of $100 \mathrm{~m}^{2}$ was established, all mangrove species were identified, and the total number of trees of each species present was recorded. The diameter at breast height $(\mathrm{DBH})$ at $1.3 \mathrm{~m}$ from the forest floor, was measured for each tree, except for species of the genus Rhizophora sp. where the diameter at $30 \mathrm{~cm}$ above the highest root of the main stem was taken (Kauffman and Donato 2012). From 
Fig. 1 Sampling locations in Singapore along the North coast (white dots) and the distribution of mangrove forest (dark green), seagrass meadows (medium green), catchment areas (light green) and tidal flats (white)

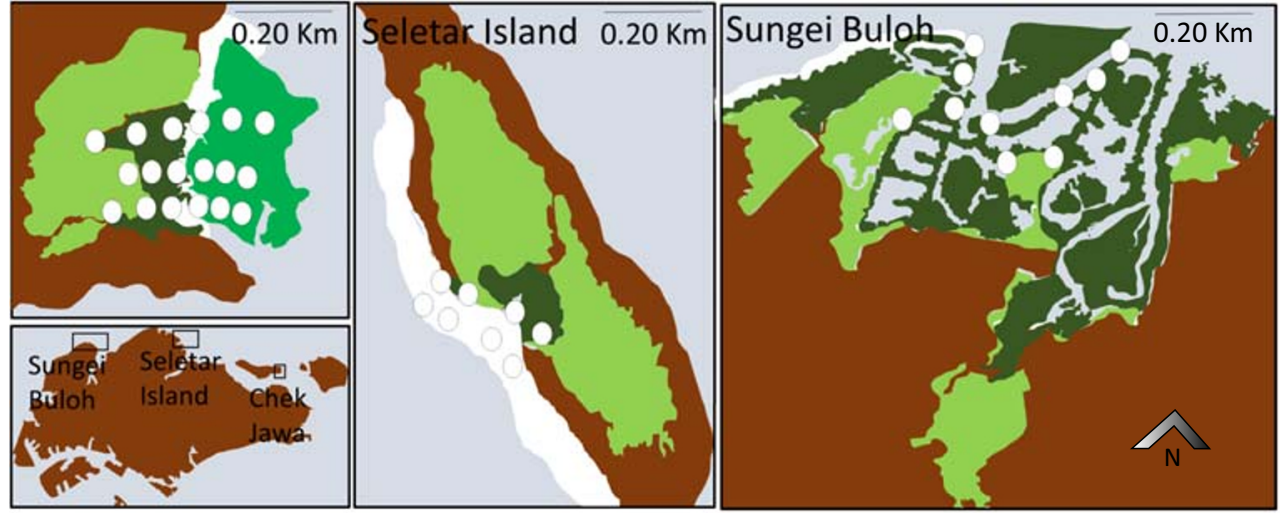

this, we estimated aboveground and belowground biomass (AGB and BGB respectively), using species-and regionspecific allometric equations (Table 1). If no allometric equation had been developed for the species, a genuslevel or general equation was used, as commonly conducted in other studies (e.g., Rahman et al. 2015). Speciesspecific wood densities were used, which is recommended if stand-specific measurements are not available (Chave et al. 2005). Carbon pools were derived from the living biomass measurements using a standard and conservative biomass-to-carbon ratio of 0.464 (Kauffman and Donato 2012).

At each transect point inside the seagrass bed a core of $15 \mathrm{~cm}$ diameter, total area of $176 \mathrm{~cm}^{2}$ and $20 \mathrm{~cm}$ depth was used to harvest seagrass ABG and BGB. Seagrass parts were cleaned and rinsed in the field with seawater, and again in the laboratory with distilled water. The amount of organic carbon in seagrass structures was calculated by multiplying $\%$ carbon content of each species by the biomass present at each point (Howard et al. 2014). Carbon content in the plant biomass and carbon stocks in the ecosystems were calculated as explained below. Carbon stocks were reported in $\mathrm{Mg}$ (megagrams) of carbon per hectare, however other units were reported in $\mathrm{mg}$ (miligrams) due to the quantities differing by at least ten orders of magnitude.

\section{Sediment Sampling}

At each point along the transects, two types of suspended sediment samples were evaluated, one from sediment traps on the sediment surface, and a second one from the water column (suspended particulate matter (SPM)).

Sediment traps were installed during low tide at a height of $0.05 \mathrm{~m}$ above the sediment. The traps were plastic cylinders of $24 \mathrm{~cm}$ length and $6 \mathrm{~cm}$ diameter, with twenty-four $0.5 \mathrm{~cm}$ diameter holes evenly distributed in the upper $10 \mathrm{~cm}$, with a lid at the bottom that collected the suspended particulate matter that entered the trap. Sediment traps were attached to steel rods that were anchored in the sediment. The traps were emptied after $24 \mathrm{~h}$. To avoid salt contamination, samples were exposed in the oven at $60{ }^{\circ} \mathrm{C}$ for $24 \mathrm{~h}$, supernatant water was carefully removed and an additional $150 \mathrm{~mL}$ of distilled water was added to dissolve remaining salt. This process was repeated until salt particles were not detected visually.

For SPM, water samples of $1 \mathrm{~L}$ from the upper $40 \mathrm{~cm}$ of the water column were taken at each point during ebb tide. Admittedly, we acknowledge that SPM being sampled at ebb tide may be biased towards mangroves and terrestrial sources, whereas sediment traps captured POM over two ebb and two flood tides. Samples were kept in freezer bags with freezer blocks and transported within $4 \mathrm{~h}$ to the
Table 1 Allometric equations used for estimation of biomass of mangrove trees using measured diameter at breast height $(\mathrm{DBH})$ and wood density $(\rho)$ of trees. Wood density values $\rho$ were obtained at (worldagroforestry. org)

\begin{tabular}{|c|c|c|c|c|}
\hline No & Species & Aboveground & Belowground & Reference \\
\hline 1 & Avicennia alba & $0.251 \rho \mathrm{DBH} 2.46$ & $0.199 \rho 0.899 \mathrm{DBH} 2.22$ & Komiyama et al. 2005 \\
\hline 2 & $\begin{array}{l}\text { Avicennia } \\
\quad \text { officinalis }\end{array}$ & $0.251 \rho \mathrm{DBH} 2.46$ & $0.199 \rho 0.899 \mathrm{DBH} 2.22$ & Komiyama et al. 2005 \\
\hline 3 & $\begin{array}{l}\text { Avicennia } \\
\quad \text { rumphiana }\end{array}$ & $0.251 \rho \mathrm{DBH} 2.46$ & $0.199 \rho 0.899 \mathrm{DBH} 2.22$ & Komiyama et al. 2005 \\
\hline 4 & $\begin{array}{l}\text { Bruguiera } \\
\text { cylindrica }\end{array}$ & $0.251 \rho \mathrm{DBH} 2.46$ & $0.199 \rho 0.899 \mathrm{DBH} 2.22$ & Komiyama et al. 2005 \\
\hline 5 & $\begin{array}{r}\text { Rhizophora } \\
\text { apiculata }\end{array}$ & $0.1709 \rho \mathrm{DBH} 2.516$ & $0.199 \rho 0.899 \mathrm{DBH} 2.22$ & $\begin{array}{l}\text { Putz and Chan 1986; Komiyama } \\
\text { et al. } 2008\end{array}$ \\
\hline 6 & $\begin{array}{l}\text { Rhizophora } \\
\text { stylosa }\end{array}$ & $0.1709 \rho \mathrm{DBH} 2.516$ & $0.199 \rho 0.899 \mathrm{DBH} 2.22$ & $\begin{array}{l}\text { Putz and Chan 1986; Komiyama } \\
\text { et al. } 2008\end{array}$ \\
\hline 7 & Sonneratia alba & $0.251 \rho \mathrm{DBH} 2.46$ & $0.199 \rho 0.899 \mathrm{DBH} 2.22$ & Komiyama et al. 2005 \\
\hline
\end{tabular}


laboratory, where they were filtered onto pre-combusted $\left(450{ }^{\circ} \mathrm{C}, 24 \mathrm{~h}\right)$ glass fiber filters $(\mathrm{GF} / \mathrm{C}, 696$ grade, $1.2 \mu \mathrm{m}$ pore diameter). Suspended particulate material, dry filters and sediment trap samples were analyzed for isotopic composition and used later in the mixing model to determine the origin of the POM.

At all transect points, a sediment core of $15 \mathrm{~cm}$ depth and $7 \mathrm{~cm}$ diameter was taken during low tide. The core was divided into three subsamples of $0-5,5-10$ and $10-15 \mathrm{~cm}$ sediment layers. The amount of organic carbon in each layer was calculated by measuring the \% OC in the sample and multiplying by sediment density (Howard et al. 2014).

\section{Water and Gas Flux Sampling}

Fluxes of $\mathrm{CO}_{2}$ were measured using a portable sampling $\mathrm{CO}_{2}$ data logger (K33-BLG CO2Meter), with an internal $\mathrm{CO}_{2}$ sensor using NDIR (non-dispersive infrared), with an accuracy of $\pm 0.2 \%$ volume $\mathrm{CO}_{2}$. The loggers were calibrated using outdoor air as a reference, having $400 \mathrm{ppm}$ as reference value, and the software DAS gas lab®. The sensor was configured with a $15 \mathrm{~cm}$ diameter light and dark (covered with aluminum foil) $9 \mathrm{~L}$ survey chamber. Light and dark chambers were used to evaluate the influence that photosynthetic microorganism could have on $\mathrm{CO}_{2}$ fluxes. $\mathrm{CO}_{2}$ flux density $\left(\mathrm{mg} \mathrm{CO} \mathrm{CO}_{2}-\mathrm{C}\right.$ $\left.\mathrm{m}^{-2} \mathrm{~h}^{-1}\right)\left(\mathrm{FCO}_{2}\right)$ was calculated following the methods and equation described by Chojnicki et al. (2009) using light and dark chambers.

$\mathrm{FCO}_{2}=\mathrm{kCO}_{2}(273 \cdot$ Tair-1 $) \cdot(\mathrm{V} \cdot \mathrm{A}-1) \cdot(\mathrm{dc} \cdot \mathrm{dt}-1)$

Where $\mathrm{kCO}_{2}$ is the gas-constant at $273.15 \mathrm{~K}=0.536(\mu \mathrm{g} \mathrm{C}$ $\mu \mathrm{l}^{-1}$ ), Tair represents the air temperature inside the chamber $(\mathrm{K}), \mathrm{V}$ is the chamber volume $(\mathrm{L}), \mathrm{A}$ is the collar area $\left(\mathrm{m}^{2}\right)$ and $\mathrm{dc} \cdot \mathrm{dt}-1$ is the rate of $\mathrm{CO}_{2}$ concentration change in chamber $\left(\mathrm{ml} \mathrm{l}^{-1} \mathrm{~h}^{-1}\right)$.

At each plot, $20 \mathrm{~mL}$ of water was taken from the water column during the ebb tide and filtered ( $45 \mu \mathrm{m}$ pore size) into pre-combusted glass vials. Samples were kept in a cooler bag with external freezer blocks and transported to the laboratory. For DOC samples, approximately $200 \mu \mathrm{L}$ of $\mathrm{HCl}$ was added to decrease $\mathrm{pH}$ below 2 , and preserved samples were transported to ZMT. Dissolved organic carbon was analyzed using an infra-red gas analyzer with a Skalar SAN System.

Samples for Chlorophyll a (Chl-a) were obtained by filtering $500 \mathrm{~mL}$ through $\mathrm{GF} / \mathrm{F}$ filters $(1.2 \mu \mathrm{m})$. After filtering, samples were stored frozen until measurements were done. All samples were transported in cooler bags with freezer blocks, before being analyzed at ZMT chemical analytical laboratories. For Chl-a, each filter was cut in pieces and left in constant agitation overnight in $8 \mathrm{~mL}$ of $96 \%$ ethanol in the dark at $20{ }^{\circ} \mathrm{C}$. Later, samples were centrifuged for $20 \mathrm{~min}$ at $5000 \mathrm{rpm}$ at $4{ }^{\circ} \mathrm{C}$. Absorbance was measured at $665 \mathrm{~nm}$ and
$470 \mathrm{~nm}$ using a photometer (Shimadzu UV-1700). Calculations of Chl-a were done following the procedure described by Ritchie (2008).

\section{Carbon Source Analysis}

Five sources of POM were considered in this study: oceanic (plankton and SPM), mangrove tree leaves, seagrass leaves, terrestrial plants leaves and macroalgal tissues. Stable isotope signatures, $\delta^{13} \mathrm{C}$ and $\delta^{15} \mathrm{~N}$, of the five different POM sources, analyzed through the Bayesian mixing model MixSIAR (Stock et al. 2018), were used for estimating the contribution of the different sources to the POM sampled in each plot. Isotopic signal values for oceanic sources used in this study were taken from studies done in Johor strait (Zhang et al. 2017), in this instance oceanic samples were mostly comprised of plankton and suspended sediment matter. The most abundant species at each mangrove location (Rhizophora apiculata, Avicennia alba, Bruguiera cylindrica, Avicennia rumphiana, Nypa fruticans (dominant only in Chek Jawa)), seagrass (Cymodocea rotundata, Halodule uninervis, Halophila ovalis), terrestrial plants (Caryota mitis, Canavalia cathartica, Barringtonia sp., Thespesia populnea, Pinus sp. (dominant only in Seletar Island)) and macroalgae (Ulva sp. and Dictyota sp.) were sampled. Fresh plant leaves (4-5) and algal thalli were taken, placed in separate sample bags and transported to the laboratory. The leaves and thalli were rinsed with distilled water and dried at $60^{\circ} \mathrm{C}$ for $48-72 \mathrm{~h}$ to constant weight.

All samples were analyzed for POC, and $\delta 13 \mathrm{C}$ and $\delta 15 \mathrm{~N}$. Sediment traps, SPM, plant, and macroalgal samples were homogenized, then acidified to remove carbonates and analyzed for OC by combustion in an elemental analyzer (EuroVector EA 3000) with a precision of $0.06 \%$ for OC and $0.01 \%$ for total nitrogen for sediments (organic soil standard), and a precision of $0.36 \%$ for OC and $0.05 \%$ for total nitrogen for plant materials (Apple leaves standard SRM1515 reference material). Carbon and nitrogen stable isotope ratios were determined using a gas isotope ratio mass spectrometer (Thermo Finnigan Delta Plus) after high temperature combustion in an elemental analyzer (Flash $1112 \mathrm{EA})$. Isotope ratios were expressed in the delta notation $(\delta 13 \mathrm{C}, \delta 15 \mathrm{~N})$ relative to Vienna PDB and atmospheric nitrogen. Analytical precision was $\pm 0.10 \%$ o for nitrogen and $0.13 \%$ o for carbon, as estimated from an international standard (Peptone) analyzed together with the samples.

\section{Data Analysis}

We compared the water parameters (DOC; Chl-a, and POC), SPM concentration, $\mathrm{CO}_{2}$ fluxes and sediment $\mathrm{OC}$ stocks across the three locations and the different ecosystems present in the intertidal zone (i.e. mangrove forest, seagrass bed or 
tidal flat). A Generalized Linear Mixed-Effects Model was constructed for each variable using location and ecosystem as a fixed effect, and the transect point within the ecosystem (MF1, MF2, SB1 etc.) as a nested random effect within each location. For carbon in AGB and BGB of mangrove trees, only location was used as the fixed effect, and the transect point within the ecosystem (MF1, MF2, etc.) was a random effect, nested within the location.

To test significant differences across the locations, transects points and the different ecosystems in each location, an Analysis of Variance (ANOVA), followed by Tukey's HSD post hoc comparisons were used. T-tests were used to test for differences between light and dark $\mathrm{CO}_{2}$ incubations. A type 1linear regression was used to evaluate the relationship between Chl-a and SPM, POC, and DOC, to evaluate the influence of phytoplankton on DOC, POC and PN.

Diagnostic plots and visual assessments of normality and homogeneity of variation were used to confirm the data conformed to major statistical assumptions (residual homogeneity, independence and normality). Statistical significance was assessed using $\alpha=0.05$. Statistical analyses were completed using R version 3.0.2 (R Core Team, 2013), using the packages ' $1 \mathrm{~m} 4$ ' for GLMM (Bates et al. 2015), 'CAR' for ANOVA (Fox and Weisberg 2011) and 'eemeans' for Tukey's HSD post hoc comparisons (Lenth et al. 2018).

For the MixSIAR, both SPM and sediment traps isotopic samples were in the range of the 5 potential sources (Fig. 6). Markov Chain Monte Carlo MCM runs with a Chain Length of 1,000,000 were selected, in order to obtain Gelman diagnostics $<1.05$. Discrimination coefficient was set at 0 (Stock et al. 2018). The relative contribution dimensionless index was calculated by dividing the contribution of each source given by the mixing model (\% Contribution) by the percent of surface area (\% Area) occupied by the respective ecosystem (terrestrial, mangrove forest, seagrass bed).

Relative Contribution $=\frac{\% \text { Contribution }}{\% \text { Area }}$

Percent of surface (\% Area) was calculated by dividing the surface area of the ecosystem (i.e. mangrove forest) by the area of the adjacent catchment terrestrial system plus the intertidal systems (mangrove forest, plus tidal flats or seagrass beds).

\section{Results}

\section{Carbon Stocks in Biomass and Sediments}

Mangrove biomass carbon stocks were significantly different across locations for above ground (GLMM; $p<0.01, \mathrm{df}=2$, $\left.\mathrm{X}^{2}=10.7\right)$ and below ground (GLMM; $\mathrm{p}<0.01, \mathrm{df}=2, \mathrm{X}^{2}=$
9.7) and ranged from 9.5 to $214.8 \mathrm{Mg} \mathrm{C} \mathrm{ha}^{-1}$ being lowest at Seletar Island (Fig. 2). Carbon stocks in seagrass plants ranged from 0.02 to $1.4 \mathrm{Mg} \mathrm{C} \mathrm{ha}^{-1}$ at Chek Jawa.

Carbon content in the top $15 \mathrm{~cm}$ of the sediment ranged from 0.2 to $0.9 \mathrm{Mg} \mathrm{C} \mathrm{ha}^{-1}$. Sediment carbon stocks in the 0 $15 \mathrm{~cm}$ did not differ significantly among mangrove locations (GLMM; $\left.p=0.06, \mathrm{df}=2, \mathrm{X}^{2}=5.5\right)$, nor were significant nested random effects detected for sediment carbon stocks for locations or transect points within the ecosystem (GLMM; $p=0.08, \mathrm{df}=1, \mathrm{X}^{2}=2.9$ ) (Fig. 2). No significant differences were found among seagrass beds, mangrove forests and terrestrial soils at Chek Jawa (GLMM; $p=0.05, \mathrm{df}=$ $2, X^{2}=5.9$ ) or at Sungei Buloh among tidal flats, mangrove forests and terrestrial soils (GLMM; $\left.p=0.5, \mathrm{df}=2, \mathrm{X}^{2}=1.4\right)$.

\section{Carbon Content in the Water Column}

Mangrove forest organic carbon (OC) was transported towards the sea with the ebb tide as dissolved organic carbon (DOC) and suspended particulate organic carbon (sPOC), the ratio of sPOC/DOC ranging on average across sampling points from 0.3 to 0.8 (Fig. $3 \mathrm{~b}$ ). There was a significant difference among locations for both DOC (GLMM; $p<0.01$, $\left.\mathrm{df}=2, \mathrm{X}^{2}=45.3\right)$ and $\mathrm{sPOC}(\mathrm{GLMM} ; p$ value $=0.03, \mathrm{df}=2$, $\mathrm{X}^{2}=6.9$ ); POC was lowest at Sungei Buloh (Fig. 3a). No random effects of the transect point within the ecosystem, were detected in any of the water parameters measured, DOC (GLMM; $p=0.8, \mathrm{df}=2, \mathrm{X}^{2}=0.5$ ) and POC (GLMM; $\left.p=0.05, \mathrm{df}=2, \mathrm{X}^{2}=5.9\right)$, indicating that neither DOC nor POC concentrations were significantly different inside the mangrove forest and the seagrass bed in Check Jawa. Further, DOC and POC concentrations did not differ significantly among mangrove forests, seagrass beds or tidal flats (Fig. 3).

No significant differences in the quantity of SPM among locations (GLMM; $p=0.2, \mathrm{df}=2, \mathrm{X}^{2}=3.6$ ) or ecosystems (GLMM; $p=0.9, \mathrm{df}=2, \mathrm{X}^{2}=0.1$ ) were observed (Fig. 4a). Chlorophyll-a and DOC showed a significant correlation $\left(p<0.01, \mathrm{R}^{2}=0.3\right)$ (Fig. 4b). Location had a significant effect on Chl-a (GLMM; p <0.01, df $=2, \mathrm{X}^{2}=31.6$ ), with Chl-a concentrations being higher at Seletar Island than the other locations (Fig. 4).

\section{Sediment $\mathrm{CO}_{2}$ Fluxes}

Fluxes of $\mathrm{CO}_{2}$ from sediment to the atmosphere were variable among transect points. Dark incubations varied between 4 and $79 \mathrm{mmol} \mathrm{CO}_{2} \mathrm{~m}^{-2} * \mathrm{~d}^{-1}$, and light incubations fluxes between 5 and $61 \mathrm{mmol} \mathrm{CO}_{2} \mathrm{~m}^{-2} * \mathrm{~d}^{-1}$ (Fig. 5). No significant differences were observed between Seletar Island and Sungei Buloh in dark (GLMM; $p=0.6, \mathrm{df}=1, \mathrm{X}^{2}=0.3$ ) or light incubations (GLMM; $\left.p=1, \mathrm{df}=1, \mathrm{X}^{2}=<0.01\right)$. Among mangrove forests and tidal flats, only Sungei Buloh presented significantly 
Fig. 2 Carbon stocks in the sediment and the biomass in coastal ecosystems of northern Singapore, portioned in aboveground, belowground biomass and sediment $(0-15 \mathrm{~cm})$. The $\mathrm{x}$-axis shows the transect point, where measurements were taken; the lowest the number is closer to the oceanic fringe of the ecosystem. Mangrove forest (MF), seagrass beds (SB); terrestrial (TE) and tidal flat (TF)

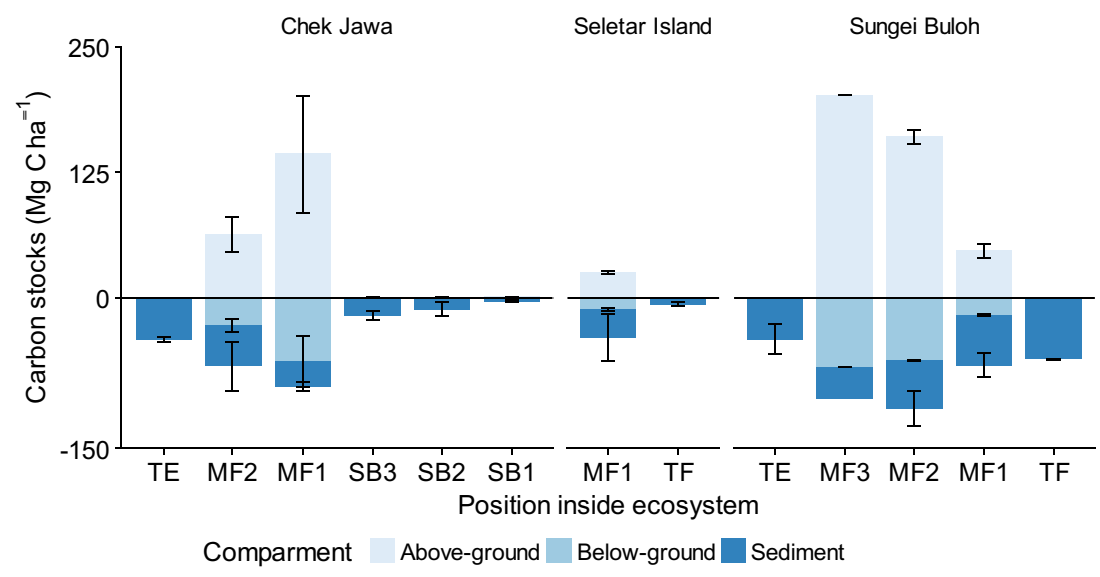

different values for light incubation (GLMM; $\mathrm{p}=<0.01, \mathrm{df}=$ $1, X^{2}=8.5$ ), being higher in tidal flats.

Overall no significant difference was observed between dark and light incubation chambers at each transect point (T-test; $p=0.4, \mathrm{df}=12, \mathrm{t}=1$ ) with the exception of transect point MF1 at Seletar Island (Fig. 5), where CO2 fluxes out of the sediment were significantly higher in dark chamber than in light chamber incubations ( $\mathrm{T}$-test; $p=0.01, \mathrm{df}=1, \mathrm{t}=63.7$ ). We did not complete a statistical test for the transect points at Sungei Buloh due to insufficient replication.

\section{Carbon Sources in SPM and Trap Samples}

The isotopic signatures of SPM grouped close to oceanic and macroalgae in Seletar Island and Chek Jawa (Fig. 6a and c), whereas Sungei Buloh samples grouped closer to the terrestrial and mangrove sources (Fig. 6a). Whilst most of the isotopic signatures of sediment trap samples grouped closer to mangrove and terrestrial sources in Sungei Buloh and Seletar Island, in Chek Jawa the signatures were spread mainly among mangrove plants, terrestrial plants, macroalgae and oceanic sources (Fig. 6b and d).

Contributions of the different sources to the POM analyzed at the different points varied among locations and between type of sample (SPM or trap). Oceanic sources were the highest contributor of POM for SPM at all locations, while sediment trap samples were dominated by mangrove POM (Fig. 7a and b). Seagrass beds were only present at Chek Jawa, and covered a smaller area than the terrestrial zone (Fig. 1), their relative contribution was similar in both SPM
Fig. 3 Organic carbon concentration in ebb tide across the mangrove forest, seagrass beds or tidal flats, DOC (solid line) and POC (dashed line) in the 3 different locations; the values are means $\pm \operatorname{SE}(n=3)$ in panel a. A ratio $\mathrm{POC} / \mathrm{DOC}$ gray line values are means $\pm \mathrm{SE}$ is shown in panel b. The $\mathrm{x}$-axis shows the transect points inside the ecosystem where samples were taken; the lowest the number is closer to the oceanic fringe of the ecosystem. Mangrove forests (MF), seagrass bed (SB), tidal flat (TF)

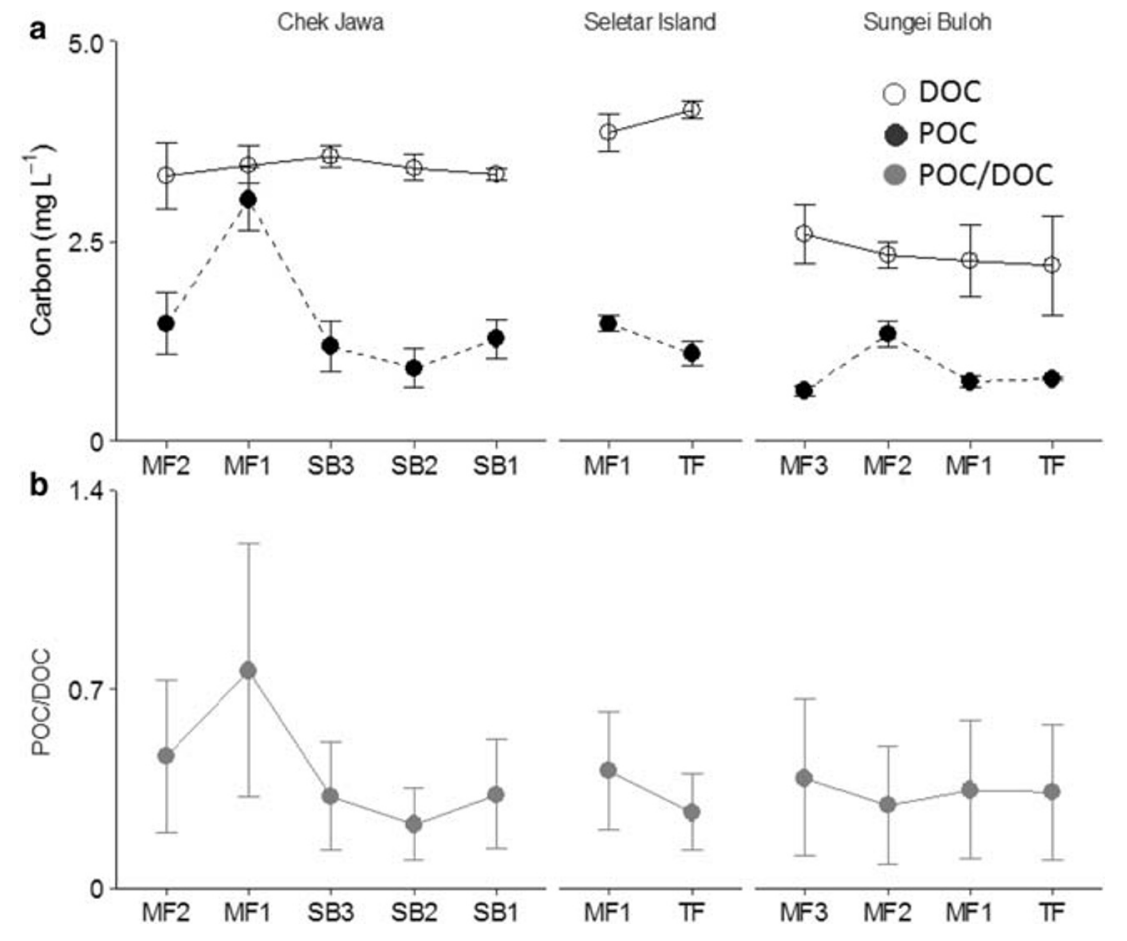




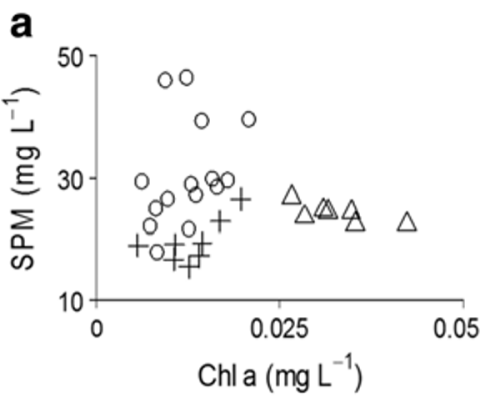

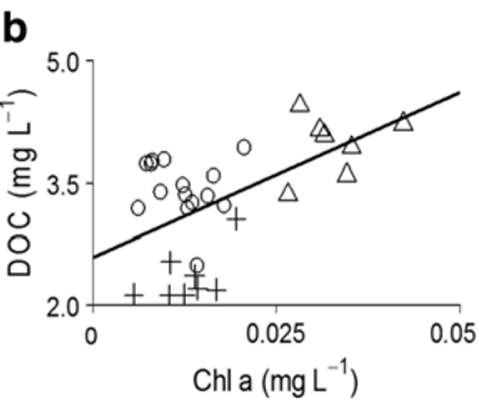

O Chek Jawa $\triangle$ Seletar Island + Sungei Buloh

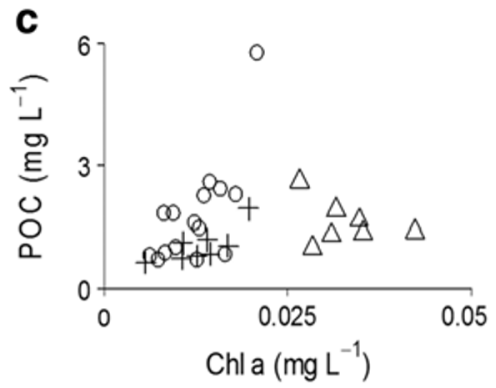

Fig. 4 Chlorophyll a (Chl-a) vs. SPM (mg L $\left.{ }^{-1}\right)$ panel A, DOC $\left(\mathrm{mg} \mathrm{L}^{-1}\right)$ panel B, POC $\left(\mathrm{mg} \mathrm{L}^{-1}\right)$ panel C and PN $\left(\mathrm{mg} \mathrm{L}^{-1}\right)$ panel D. Different shapes indicate different locations indicated in the legend. A linear

and trap samples (Fig. 7c and d). The relative contributions showed that mangrove forests were the greatest contributor of the three ecosystems with fixed area (mangrove, seagrass, terrestrial) at all locations and for all samples except for the SPM samples in Sungei Buloh.

Suspended particulate matter samples exhibited greater contribution of terrestrial sources than sediment trap samples at all locations. Seagrass beds were not a strong contributor of POM in SPM or sediment traps samples (Fig. 7a and b). However, at Chek Jawa the contribution of macroalgae was higher than that of seagrass in both SPM and sediment traps samples (Fig. 7).

\section{Discussion}

\section{Carbon Stocks, Carbon in the Ebb Tide and $\mathrm{CO}_{2}$ Fluxes}

Despite similar climatic conditions, mangrove forests in Northern Singapore exhibited differing standing biomass stocks, but carbon stocks in, and $\mathrm{CO}_{2}$ fluxes from, the upper sediment layers $0-15 \mathrm{~cm}$ showed no difference. Mangrove forests at Sungei Buloh presented the highest carbon stocks correlation (solid line) was found in Chl-a vs. DOC in panel B. No significant correlation was observed between Chl-a vs. SPM panel A, Chl-a vs. POC, panel C

(Fig. 2), and Sungei Buloh also had the largest mangrove forest cover with a higher riverine/fresh water influence and terrestrial contribution than Chek Jawa and Seletar Island (Figs. 1 and 2). Carbon stocks in the upper sediment layer $(0-15 \mathrm{~cm})$ did not significantly differ among mangrove forests, terrestrial forests, tidal flats and seagrass beds at each location. This could mainly be due to high variability of organic carbon content in the sediment across the sampled transect points especially at the mangrove forests. Mangroves at Seletar Island were smaller, patchier, and without riverine influence (Fig. 1), and as such showed lower aboveground carbon stocks (Fig. 2). Results of this study, compared to a previous study of mangrove above- and belowground biomass measurements in northern Singapore, were lower at Chek Jawa (Phang et al. 2015) but similar or higher at Sungei Buloh (Friess et al. 2016). However, variation may be due to differences in specific sampling sites, temporal variation, or calculations of carbon biomass methods between the studies. Mangrove forests in Singapore, as well as other mangrove forests, show spatial variation in biomass density, and therefore in carbon stocks observed between the locations, corroborating a common pattern in mangrove forests, due to variation in natural factors such as geomorphic setting and previous
Fig. 5 Dark and light chambers incubation $\mathrm{CO}_{2}$ fluxes in coastal mangrove forest (MF) and tidal flat (TF) in Seletar Island and Sungei Buloh. The $\mathrm{x}$-axis shows the transect point inside the ecosystem where measurements were taken; the lowest the number is closer to the oceanic fringe of the ecosystem. Mangrove forests (MF) and tidal flat (TF). The values are means $\pm S E$ ( $n=3$ for all except for MF1 and MF3 in Sungei Buloh where only one measurement was taken)

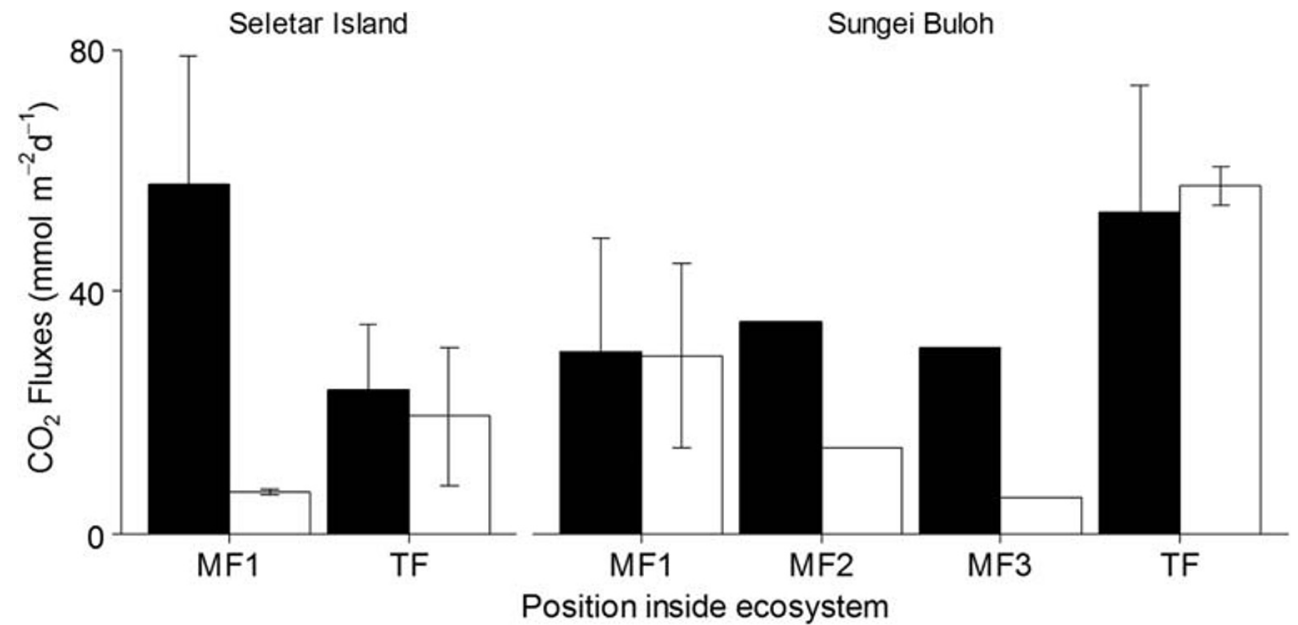


SPM

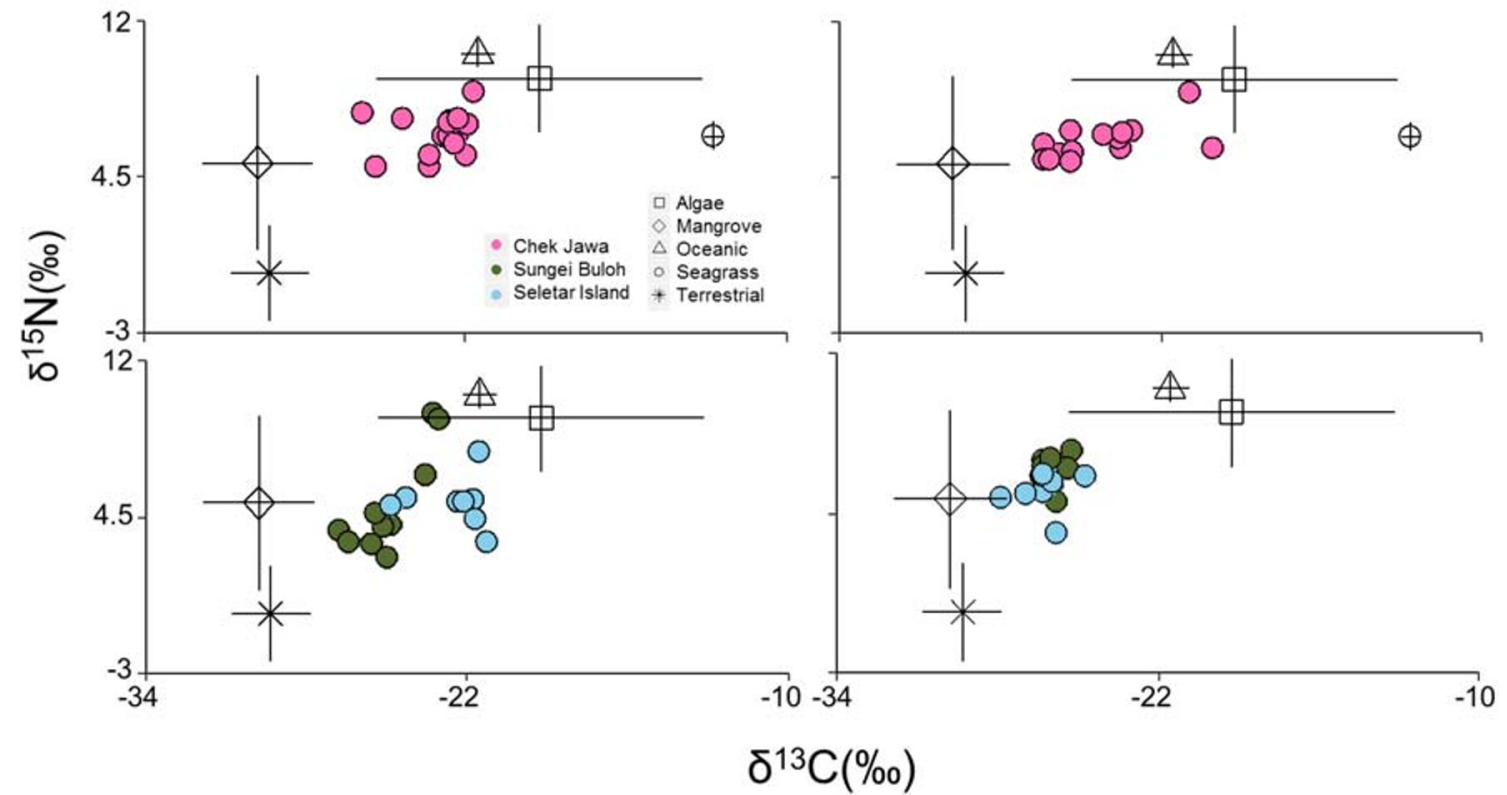

Fig. 6 Scatter plots with isotopic of carbon $(813 \mathrm{C}$ o/oo $)$ and nitrogen $(\delta 15 \mathrm{~N} \mathrm{o} / \mathrm{oo})$ composition of suspended particulate matter (SPM) (Panel A and C) and sediment trap samples (Panel B and D). Sources are expressed as mean $\pm \mathrm{SE}$ in different shapes without fill, in Isolated locations only 4 sources (Panel C and D), see legend for details. Check Jawa was the only connected location therefore the only location where seagrass were used as a source (Panel A and B) a

SPM

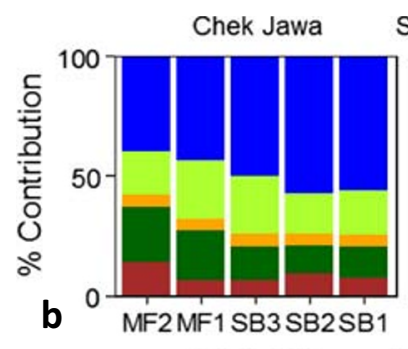

Seletar Island Sungei Buloh

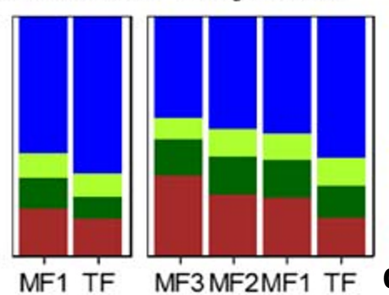

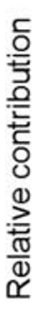

Chek Jawa

Seletar Island

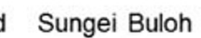

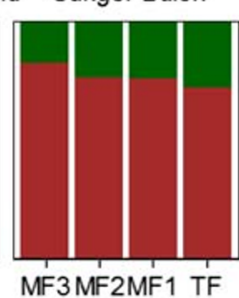

C

Sediment traps
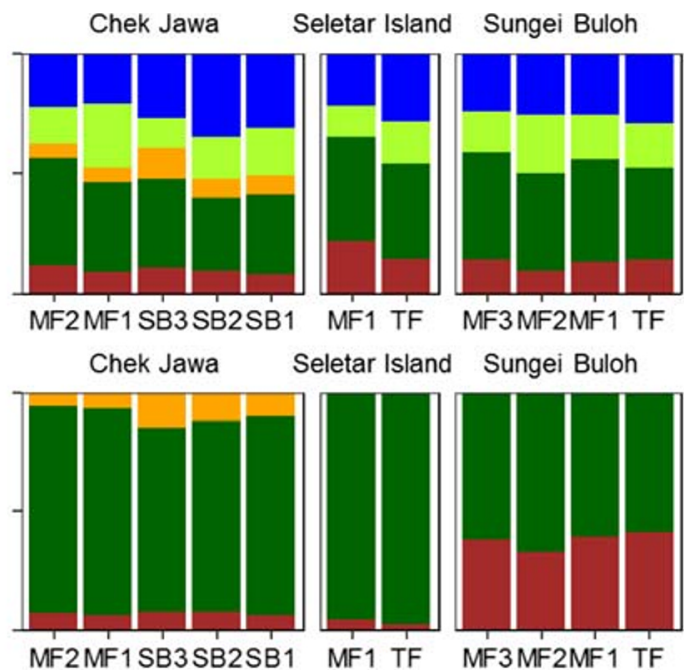

Transect point

Transect point

Oceanic

Macroalgae

Seagrass plants
SPM and sediment trap samples. X-axis shows the transect points inside the ecosystem where samples were taken; mangrove forests (MF), seagrass bed (SB), tidal flat (TF). The lowest the number is closer to the oceanic fringe of the ecosystem. Different colors indicate different sources indicated in the legend 
disturbances (e.g., Ewel et al. 1998; Rovai et al. 2018; Ward et al. 2017).

Mangrove forest organic carbon (OC) was transported towards the sea on the ebb tide as dissolved organic carbon (DOC) and suspended particulate organic carbon (sPOC), the ratio of $\mathrm{SPOC}$ and DOC ranging in average from 0.3 to 0.8 (Fig. 3); this is consistent with other reports where DOC was higher than $\mathrm{SPOC}$ in mangrove systems (Bouillon et al. 2007; Dittmar and Lara 2001; Taillardat et al. 2018). Dissolved organic carbon and sPOC was lower in Sungei Buloh than at other locations. We found a positive correlation between DOC and Chl-a concentrations (Fig. 4b), suggesting that DOC could be derived mostly from phytoplankton. Phytoplankton has been shown to influence the DOC concentration by passive leakage and active exudation (Thornton 2014) and by cell lysis (Agustí and Duarte 2013). Nonetheless, further research elucidating the origin of DOC is necessary in order to measure the contribution of different ecosystem sources to transported organic carbon, since in this study DOC had higher concentration than sPOC (Fig. 3).

In general, $\mathrm{CO}_{2}$ fluxes were highly variable, with no significant differences between Sungei Buloh and Seletar Island. Different studies have shown that densely vegetated and conserved mangrove forest sediments appear to have lower fluxes of $\mathrm{CO}_{2}$, compared with clear-cut forests (Lovelock et al. 2011; Gillis et al. 2017; Kristensen et al. 2008) or strongly eutrophic forests (Chen et al. 2010). Physical and biological factors such as tidal regime, nutrient content in the sediment, and presence of biofilms have been shown to influence the $\mathrm{CO}_{2}$ fluxes from the sediment (Alongi 2014; Kristensen et al. 2008). Fluxes of $\mathrm{CO}_{2}$ in Shenzhen and Hong Kong, South China, were positively correlated with soil organic carbon, total nitrogen, total phosphate, total iron, ammonium and soil porosity (Chen et al. 2010). Light chamber fluxes of $\mathrm{CO}_{2}$ tend to be lower than dark fluxes, indicating the importance of biofilms in terms of CO2-uptake upon photosynthesis. The activity of photosynthetic microbial communities is also important in retaining carbon from respiration within the ecosystem (Lovelock 2008) and the formation of biofilms may create a physical barrier by clogging the pore space (Leopold et al. 2013). We found differences in the mangrove forest and tidal flat in Sungei Buloh (Fig. 5), with light chamber $\mathrm{CO}_{2}$ fluxes being higher on tidal flats, where sediments were mainly muddy with no visual presence of benthic microalgae biofilms. In mangrove forests, $\mathrm{CO}_{2}$ light chamber fluxes were lower indicating either more oxygen production or less respiration under light conditions. Data of this study is limited to conclude which process is occurring since we did not remove the biofilms of the sediments to measure $\mathrm{CO}_{2}$ fluxes and we could not measure $\mathrm{CO}_{2}$ fluxes in Chek Jawa. Additional studies including different tidal regimes and removal of biofilms will help to determine what controls $\mathrm{CO}_{2}$ fluxes in Singapore mangrove forest. As we found no differences across locations and only in one location light chambers show between mangrove forest and seagrass beds.

\section{Mangrove Forests and Adjacent Ecosystems: Donors and Recipients}

While climatically similar, the mangrove forests in this study had different local geomorphic settings and landscape structures, such as higher riverine influence in Sungei Buloh, fringing patches of mangrove forests in Seletar Island, and fringing mangrove forests with an adjacent seagrass bed in Chek Jawa (Fig. 1). Sampling was completed during late Northeast Monsoon, which is a season of low rainfall and high wind speeds, suggesting that POM from runoff within the catchment area contributed little during this time of the year. We hypothesize that the influence of terrestrial plants will be higher during highly rainy seasons due to the higher input of terrestrially derived POM. However, further studies are needed to test this hypothesis.

The transport of POC from mangroves to adjacent ecosystems depends on different factors, such as river discharge, surface area of ecosystems, estuarine geomorphology and hydrodynamics (Hyndes et al. 2014). Geomorphic settings corresponded to the isotopic signal of SPM samples. For example, Sungei Buloh (riverine location) had isotopic signals closer to mangrove trees and terrestrial plants, while fringing locations had signals closer to oceanic and macroalgal sources (Figs. 1 and 6). The geomorphic setting of Sungei Buloh facilitates the transport of detrital material from terrestrial plants and mangrove trees into coastal water bodies due to channelassociated water movement. Samples of SPM at Sungei Buloh showed a higher terrestrial contribution than the other locations (Fig. 7a), as Sungei Buloh is influenced by upstream freshwater sources containing terrestrial plant detritus (Fig. 1). In general, the biggest contribution of all sediment trap samples were mangrove vegetation (Fig. $7 b$ and d), as indicated by the closer grouping of all samples to the isotopic signatures of mangrove tress (Fig. $6 \mathrm{~b}$ and d). While fringing mangrove forests, such as Chek jawa and Seletar island, are less likely to have terrestrial inputs to the POM, due to the lack of water inflow from the catchment area. Therefore, we hypothesize that exchange of POM between terrestrial and coastal waters would be mainly driven by wind action or runoff. At Seletar Island, the terrestrial plant sources are located closer to the oceanic fringe, hence, leaves move easily (i.e. via wind action) and therefore are transported out with the wave currents faster. In Chek Java, the terrestrial plant area is isolated 
from the ocean by the mangrove forest (Fig. 1) showing a higher contribution of mangrove trees to the POM than Sungei Buloh (Fig. 7).

According to the relative contribution dimensionless index (Eq. 2), catchment areas contributed relatively (as per unit area) more to POM than seagrass in Chek Jawa, whereas the mangrove forest contributed relatively more to POM than the catchment area in Seletar Island. In contrast, the relative POM contribution of the catchment area was higher than that of the mangrove forest in Sungei Buloh (Fig. 7c). The relative contribution was not calculated for oceanic and macroalgal sources, because no representative surface area for the 'ocean' could be calculated. Additionally, we suspect that the macroalgae found in the mangrove forest were mainly allochthonous and transported by local currents, since collected algae were not attached to any hard substrate. Local geomorphological setting together with local differences in hydrodynamics will influence the relative contribution of vegetated coastal ecosystems and catchment area. However, more studies with more with different landscape structure mangrove forests are necessary to understand those processes, since patch size and seascape configuration are rarely included in connectivity studies, and if so mainly focus on fish (Boström et al. 2011). In addition to landscape structure, information on litter production and decay will be necessary for understanding the contributions of each primary producer, since it has been shown that decay rates are slower for mangrove trees and terrestrial plants, intermediate for seagrass plants and fast for macroalgae (Kristensen, 1994; reviewed in Zimmer 2019).

High oceanic contribution was found in SPM samples (Fig. 7a), corroborating former studies (Almahasheer et al. 2017; Gao et al. 2012; Gillis et al. 2014b) and stressing the importance of ocean-derived input for coastal ecosystems (Orr et al. 2005). Inputs of detritus from adjacent ecosystems (i.e. seagrass and macroalgal beds) can enhance sediment respiration (Lovelock 2008). Even though the catchment area was smaller than the seagrass bed in Chek Jawa, terrestrial plants had a greater contribution to the POM. Isotopic signatures of SPM grouped closer to oceanic and macroalgae, while sediment trap samples grouped closer to terrestrial and mangrove sources (Fig. 6). According to these findings, as well as the results of the MixSIAR models (Fig. 7), seagrass did not contribute markedly. Seagrass beds have been reported significant donors of POM in other studies (Almahasheer et al. 2017; Gillis et al. 2014b). However, these studies reported larger seagrass beds dominated by larger species, such as Enhalus acoroides. Seagrass beds in the study area, by contrast, are relatively small and dominated by smaller species like Cymodocea rotundata, Halodule uninervis, and Halophila spp. (Phang et al. 2015). The contribution of seagrass beds could be more important than macroalgal contributions in long-term sediment carbon stocks at the coastal and seascape level, as they are formed by recalcitrant compounds, which could be buried for a longer period within sediments (Trevathan-Tackett et al. 2017).

While we did not measure the standing biomass of all primary producers, we assumed that macroalgal biomass was less than mangrove trees, seagrass and terrestrial plants biomass. However, macroalgal contributions were larger than, or almost equal to, those of mangrove trees or terrestrial plants in fringing landscape structure (i.e. Chek Jawa) (Fig. 7). Particulate organic matter had a higher percentage of material derived from macroalgae than from seagrass plants in Chek Jawa. (Fig. 7a and b). Contrary, in Sungei Buloh (riverine geomorphic setting), even macroalgae contributed more than terrestrial plants to sediment trap samples, they contributed equal to, or less than, mangrove trees and oceanic sources, and they were the smallest contributors of SPM samples. Those results highlight that despite their low biomass, macroalgae are an important source of POM for fringing mangroves along the northern coast of Singapore. The role of macroalgae has been discussed as a potential carbon donor to adjacent ecosystems, due to algal material being exported and stored into adjacent habitats (Hill et al. 2015; KrauseJensen et al. 2018). Macroalgal carbon compounds degrade faster, being released in form of DOC or $\mathrm{CO}_{2}$ (Hill et al. 2015; Krause-Jensen et al. 2018; Mews et al. 2006). The presence of refractory macroalgal compounds (carbonates, long-chain lipids, alginates, xylans, and sulfated polysaccharides), combined with factors such as retention time in the coastal habitat, fast burial, and anaerobic decay, could render macroalgae a significant contributor to long-term carbon storage (Trevathan-Tackett et al. 2015). However, further research is needed to quantify these contributions (Hill et al. 2015). To our knowledge, no research has focused on the exchange of POM derived from macroalgae in the tropics; our results suggest that the contribution of macroalgae could be significant in understanding carbon dynamics in tropical coastal areas.

Other studies have shown that mangrove forests that extend inland may retain much of their POM and nutrients of allochthonous origin (Adame and Lovelock 2011; Alongi et al. 2016). Interactions between productivity, geomorphology and hydrology influence the connectivity of ecosystems, changes in connectivity could alter the exchange and storage of organic matter provided by mangrove forests (Alongi 2014; Feller et al. 2010). Recently, a global study showed the influence of coastal morphology on carbon budgets (Twilley et al. 2018). They found that mangrove stocks in the sediment varied markedly across different types of coastal environmental settings, increasing from river-dominated to tide/wavedominated to carbonate coastlines, but independently of forest 
architecture. Our results also showed that local landscape structure were important for carbon stocks and for connectivity in the sense of the exchange of organic matter. In our study location, mangrove forests with riverine influence (Sungei Buloh) and with seagrass beds (Chek Jawa) tend to have higher carbon stocks i.e. and compared to Seletar Island. Nevertheless, further studies evaluating these and additionally landscape structure interactions will help to further understand carbon dynamics.

\section{Conclusions}

In order to sustain carbon storage provided by coastal ecosystems, geomorphological settings and ecosystem connectivity should be taken into account in conservation and restoration plans. Mangrove forests clearly contributed the most to POM across the intertidal landscape, with differences in contributions from different primary producers across different landscape spatial arrangements. Therefore, anthropogenic induced modifications of local geomorphic settings at the coastal level (i.e. reduction of mangrove forests area or changing fresh water fluxes) may affect carbon accumulation in mangrove forests and adjacent coastal ecosystems. Conversely, active human modifications of local geomorphic settings may also increase carbon sequestration in mangrove forests and adjacent coastal ecosystems, such as seagrass and tidal flats. Further studies determining the origin of DOC together with tidal fluxes will help to elucidate the role of hydrodynamics, driven by the geomorphic setting, in the interchange and sequestration of dissolved and particulate organic carbon at the coastal landscape level.

Acknowledgments This research was conducted under the National Parks Board research permit NP/RP16-175 and NP/RP16-175a. We thank staff at NParks, Government of Singapore for logistical assistance and access to the study locations. We thank lab staff at ZMT and at the NUS for support during sample analysis. This study was funded by the DFG (Deutsche Forschungsgemeinschaft), project Number (GI 121011$1)$. We are grateful to two anonymous reviewers who contributed with critical and important comments to substantially improving our manuscript.

Funding Open access funding provided by Projekt DEAL.

\section{Compliance with ethical standards}

Data Repository Data used in this study will be deposited at scientific data repository of ZMT.

Open Access This article is licensed under a Creative Commons Attribution 4.0 International License, which permits use, sharing, adaptation, distribution and reproduction in any medium or format, as long as you give appropriate credit to the original author(s) and the source, provide a link to the Creative Commons licence, and indicate if changes were made. The images or other third party material in this article are included in the article's Creative Commons licence, unless indicated otherwise in a credit line to the material. If material is not included in the article's Creative Commons licence and your intended use is not permitted by statutory regulation or exceeds the permitted use, you will need to obtain permission directly from the copyright holder. To view a copy of this licence, visit http://creativecommons.org/licenses/by/4.0/.

\section{References}

Adame MF, Lovelock CE (2011) Carbon and nutrient exchange of mangrove forests with the coastal ocean. Hydrobiologia 663(1):23-50. https://doi.org/10.1007/s10750-010-0554-7

Agustí S, Duarte CM (2013) Phytoplankton lysis predicts dissolved organic carbon release in marine plankton communities. Biogeosciences 10(3):1259-1264. https://doi.org/10.5194/bg-101259-2013

Almahasheer H, Serrano O, Duarte CM, Arias-Ortiz A, Masque P, Irigoien X (2017) Low carbon sink capacity of Red Sea mangroves. Scientific Reports 7(1):9700. https://doi.org/10.1038/s41598-01710424-9

Alongi DM (2014) Carbon cycling and storage in mangrove forests. Annual Review of Marine Science 6:195-219. https://doi.org/10. 1146/annurev-marine-010213-135020

Alongi DM, Murdiyarso D, Fourqurean JW, Kauffman JB, Hutahaean A, Crooks S, Lovelock CE, Howard J, Herr D, Fortes M, Pidgeon E, Wagey T (2016) Indonesia's blue carbon: a globally significant and vulnerable sink for seagrass and mangrove carbon. Wetlands Ecology and Management 24(1):3-13. https://doi.org/10.1007/ s11273-015-9446-y

Bates D, Mächler M, Bolker BM, Waker SC (2015) Fitting linear mixedeffects models using lme4 Douglas. Journal of Statistical Software 67(1). https://doi.org/10.18637/jss.v067.i01

Bhomia RK, Kauffman JB, McFadden TN (2016) Ecosystem carbon stocks of mangrove forests along the Pacific and Caribbean coasts of Honduras. Wetlands Ecology and Management 24(2):187-201. https://doi.org/10.1007/s11273-016-9483-1

Boström C, Pittman S, Simenstad C, Kneib R (2011) Seascape ecology of coastal biogenic habitats: advances, gaps, and challenges. Marine Ecology Progress Series 427:191-218. https://doi.org/10.3354/ meps09051

Bouillon S, Connolly RM (2009) Carbon exchange among tropical coastal ecosystems. In: Nagelkerken I (ed) Ecological connectivity among tropical coastal ecosystems. Springer Netherlands, Dordrecht, pp 45-70. https://doi.org/10.1007/978-90-481-2406-0_3

Bouillon S, Dehairs F, Velimirov B, Abril G, Borges AV (2007) Dynamics of organic and inorganic carbon across contiguous mangrove and seagrass systems (Gazi Bay, Kenya). Journal of Geophysical Research - Biogeosciences 112(2):1-14. https://doi. org/10.1029/2006JG000325

Bouillon S, Borges AV, Castañeda-Moya E, Diele K, Dittmar T, Duke NC et al (2008) Mangrove production and carbon sinks: a revision of global budget estimates. Global Biogeochemical Cycles 22(2):1-12. https://doi.org/10.1029/2007GB003052

Chave J, Andalo C, Brown S, Cairns MA, Chambers JQ, Eamus D, Fölster H, Fromard F, Higuchi N, Kira T, Lescure JP, Nelson BW, Ogawa H, Puig H, Riéra B, Yamakura T (2005) Tree allometry and improved estimation of carbon stocks and balance in tropical forests. Oecologia 145(1):87-99. https://doi.org/10.1007/s00442-0050100-x

Chen GC, Tam NFY, Ye Y (2010) Summer fluxes of atmospheric greenhouse gases $\mathrm{N}_{2} \mathrm{O}, \mathrm{CH}_{4}$ and $\mathrm{CO}_{2}$ from mangrove soil in South China. Science of the Total Environment 408(13):2761-2767. https://doi. org/10.1016/j.scitotenv.2010.03.007 
Chojnicki BH, Michalak M, Acosta M, Juszczak R, Augustin J, Drösler M, Olejnik J (2009) Measurements of carbon dioxide fluxes by chamber method at the Rzecin wetland ecosystem, Poland. Polish Journal of Environmental Studies 19(2):283-291

Dittmar T, Lara RJ (2001) Driving forces behind nutrient and organic matter dynamics in a mangrove Tidal Creek in North Brazil. Estuarine, Coastal and Shelf Science 52:249-259. https://doi.org/ 10.1006/ecss.2000.0743

Dittmar T, de Rezende CE, Manecki M, Niggemann J, Coelho Ovalle AR, Stubbins A, Bernardes MC (2012) Continuous flux of dissolved black carbon from a vanished tropical forest biome. Nature Geoscience 5(9):618-622. https://doi.org/10.1038/ngeo1541

Duarte CM, Losada IJ, Hendriks IE, Mazarrasa I, Marba N (2013) The role of coastal plant communities for climate change mitigation and adaptation. Nature Climate Change 3(11):961-968. https://doi.org/ $10.2307 / 2997700$

Ewel K, Twilley R, Ong JE (1998) Different kinds of mangrove forests provide different goods and services. Global Ecology and Biogeography Letters 7:83-94

Feller IC, Lovelock CE, Berger U, McKee KL, Joye SB, Ball MC (2010) Biocomplexity in mangrove ecosystems. Annual Review of Marine Science 2:395-417. https://doi.org/10.1146/annurev.marine. 010908.163809

Fox J, Weisberg S (2011) An R companion to applied regression, 2nd edn. Sage. URL, Thousand Oaks http://socserv.socsci.mcmaster.ca/ jfox/Books/Companion

Friess DA, Richards DR, Phang VXH (2016) Mangrove forests store high densities of carbon across the tropical urban landscape of Singapore. Urban Ecosystem 19(2):795-810. https://doi.org/10.1007/s11252015-0511-3

Gao X, Yang Y, Wang C (2012) Geochemistry of organic carbon and nitrogen in surface sediments of coastal Bohai Bay inferred from their ratios and stable isotopic signatures. Marine Pollution Bulletin 64(6):1148-1155. https://doi.org/10.1016/j.marpolbul.2012.03.028

Gillis LG, Bouma TJ, Jones CG, Van Katwijk MM, Nagelkerken I, Jeuken CJL et al (2014a) A. Potential for landscape-scale positive interactions among tropical marine ecosystems. Marine Ecology Progress Series 503:289-303. https://doi.org/10.3354/meps10716

Gillis LG, Ziegler AD, Van Oevelen D, Cathalot C, Herman PMJ, Wolters JW, Bouma TJ (2014b) Tiny is mighty: Seagrass beds have a large role in the export of organic material in the tropical coastal zone. PLoS ONE 9(11). https://doi.org/10.1371/journal.pone. 0111847

Gillis LG, Belshe FE, Ziegler AD, Bouma TJ (2017) Driving forces of organic carbon spatial distribution in the tropical seascape. Journal of Sea Research 120:35-40. https://doi.org/10.1016/j.seares.2016. 12.006

Hill R, Bellgrove A, Macreadie PI, Petrou K, Beardall J, Steven A, Ralph PJ (2015) Can macroalgae contribute to blue carbon? An Australian perspective. 2:1689-1706. https://doi.org/10.1002/lno.10128

Howard J, Hoyt S, Isensee K, Telszewski M, Pidgeon E (eds) (2014) Coastal blue carbon: methods for assessing carbon stocks and emissions factors in mangroves, tidal salt marshes, and Seagrasses. Conservation International, intergovernmental oceanographic commission of UNESCO, International Union for Conservation of nature, Arlington

Huxham M, Whitlock D, Githaiga M, Dencer-Brown A (2018) Carbon in the coastal seascape: how interactions between mangrove forests, Seagrass meadows and tidal marshes influence carbon storage. Current Forestry Reports 4(2):101-110. https://doi.org/10.1007/ s40725-018-0077-4

Hyndes GA, Nagelkerken I, Mcleod RJ, Connolly RM, Lavery PS, Vanderklift MA (2014) Mechanisms and ecological role of carbon transfer within coastal seascapes. Biological Reviews 89(1):232254. https://doi.org/10.1111/brv.12055
Kauffman J, Donato DC (2012) Protocols for the measurement, monitoring and reporting of structure, biomass and carbon stocks in mangrove forests. Center for International Forestry Research. Working paper 86. CIFOR, Bogor, Indonesia

Kauffman JB, Heider C, Cole TG, Dwire KA, Donato DC (2011) Ecosystem carbon stocks of micronesian mangrove forests. Wetlands 31(2):343-352. https://doi.org/10.1007/s13157-0110148-9

Komiyama A, Poungparn S, Kato S (2005) Common allometric equations for estimating the tree weight of mangroves. Journal of Tropical Ecology 21(4):471-477. https://doi.org/10.1017/ S0266467405002476

Krause-Jensen D, Lavery P, Serrano O, Marbà N, Masque P, Duarte CM (2018) Sequestration of macroalgal carbon: the elephant in the blue carbon room. Biology Letters 14(6). https://doi.org/10.1098/rsbl. 2018.0236

Kristensen E (1994) Decomposition of macroalgae, vascular plants and sediment detritus in seawater: Use of stepwise thermogravimetry. Biogeochemistry 26:1. https://doi.org/10.1007/BF02180401

Kristensen E, Flindt MR, Ulomi S, Borges AV, Abril G, Bouillon S (2008) Emission of $\mathrm{CO}_{2}$ and $\mathrm{CH}_{4}$ to the atmosphere by sediments and open waters in two Tanzanian mangrove forests. Marine Ecology Progress Series 370:53-67. https://doi.org/10.3354/ meps07642

Lenth R (2018) Emmeans: Estimated marginal means, aka least-squares means. Retrieved from

Leopold A, Marchand C, Deborde J, Chaduteau C, Allenbach M (2013) Influence of mangrove zonation on $\mathrm{CO}_{2}$ fluxes at the sediment-air interface (New Caledonia). Geoderma 202-203:62-70. https://doi. org/10.1016/j.geoderma.2013.03.008

Lovelock CE (2008) Soil respiration and belowground carbon allocation in mangrove forests. Ecosystems 11(2):342-354. https://doi.org/10. 1007/s10021-008-9125-4

Lovelock CE, Duarte CM (2019) Dimensions of blue carbon and emerging perspectives 15 biology letter. Doi: https://doi.org/10.1098/rsbl. 2018.0781

Lovelock CE, Ruess RW, Feller IC (2011) $\mathrm{CO}_{2}$ efflux from cleared mangrove peat. PLoS ONE 6(6):1-4. https://doi.org/10.1371/journal. pone.0021279

Mews M, Zimmer M, Jelinski DE (2006) Species-specific decomposition rates of beach-cast wrack in Barkley sound, British Columbia, Canada. Marine Ecology Progress Series 328:155-160. https://doi. org $/ 10.3354 /$ meps 328155

Murdiyarso D, Purbopuspito J, Kauffman JB, Warren MW, Sasmito SD, Donato DC et al (2015) The potential of Indonesian mangrove forests for global climate change mitigation. Nature Climate Change 5(12):1089-1092. https://doi.org/10.1038/nclimate2734

Olds AD, Connolly RM, Pitt KA, Pittman SJ, Maxwell PS, Huijbers CM et al (2016) Quantifying the conservation value of seascape connectivity: a global synthesis. Global Ecology and Biogeography 25(1): 3-15. https://doi.org/10.1111/geb.12388

Orr JC, Fabry VJ, Aumont O, Bopp L, Doney SC, Feely RA, Gnanadesikan A, Gruber N, Ishida A, Joos F, Key RM, Lindsay K, Maier-Reimer E, Matear R, Monfray P, Mouchet A, Najjar RG, Plattner GK, Rodgers KB, Sabine CL, Sarmiento JL, Schlitzer R, Slater RD, Totterdell IJ, Weirig MF, Yamanaka Y, Yool A (2005) Anthropogenic Ocean acidification over the twenty-first century and its impact on calcifying organisms. Nature 437:681-686. https://doi. org/10.1038/nature04095

Phang VXH, Chou LM, Friess DA (2015) Ecosystem carbon stocks across a tropical intertidal habitat mosaic of mangrove forest, seagrass meadow, mudflat and sandbar. Earth Surface Processes and Landforms 40(10):1387-1400. https://doi.org/10.1002/esp. 3745

Putz FE, Chan HT (1986) Tree growth, dynamics, and productivity in a mature mangrove Forest in Malaysia. Forest Ecology and 
Management 17(2):211-230. https://doi.org/10.1016/03781127(86)90113-1

R Core Team (2013) R: A language and environment for statistical computing. R Foundation for Statistical Computing, Vienna, Austria. http://www.R-project.org/

Rahman MM, Khan MNI, Hoque AKF, Ahmed I (2015) Carbon Stock in the Sundarbans mangrove Forest: spatial variations in vegetation types and salinity zones. Wetlands Ecology and Management 23(2):269-283. https://doi.org/10.1007/s11273-014-9379-x

Ritchie RJ (2008) Universal chlorophyll equations for estimating chlorophylls a, b, c, and total chlorophylls in natural assemblages of photosynthetic organisms using acetone, methanol, or ethanol solvents. Photosynthetica 46(1):115-126. https://doi.org/10.1007/s11099008-0019-7

Rovai AS, Twilley RR, Castañeda-Moya E, Riul P, Cifuentes-Jara M, Manrow-Villalobos M, Horta PA, Simonassi JC, Fonseca AL, Pagliosa PR (2018) Global controls on carbon storage in mangrove soils. Nature Climate Change 8:534-538. https://doi.org/10.1038/ s41558-018-0162-5

Simard M, Fatoyinbo L, Smetanka C, Rivera-Monroy VH, CastañedaMoya E, Thomas N, Van Der Stocken T (2019) MangroveCanopy height globally related to precipitation, temperature and cyclone frequency. Nature Geoscience 12:40-45. https://doi.org/10.1038/ s41561-018-0279-1

Stock BC, Jackson AL, Ward EJ, Parnell AC, Phillips DL, Semmens BX (2018) Analyzing mixing systems using a new generation of Bayesian tracer mixing models. PeerJ 6:e5096. https://doi.org/10. 7717/peerj.5096

Taillardat P, Ziegler AD, Friess DA, Widory D, Marchand C, Van VT, David F (2018) Carbon dynamics and inconstant porewater input in a mangrove tidal creek over contrasting seasons and tidal amplitudes. Geochimica et Cosmochimica Acta 237:32-48. https://doi. org/10.1016/j.gca.2018.06.012

Thornton DCO (2014) Dissolved organic matter (DOM) release by phytoplankton in the contemporary and future ocean. European Journal of Phycology 49(1):20-46. https://doi.org/10.1080/09670262.2013. 875596

Trevathan-Tackett SM, Kelleway J, Macreadie PI, Beardall J, Ralph P, Bellgrove A (2015) Comparison of marine macrophytes for their contributions to blue carbon sequestration. Ecology 96(11):30433057. https://doi.org/10.1890/15-0149.1

Trevathan-tackett SM, Macreadie PI, Sanderman J, Mateo MA (2017) A global assessment of the chemical recalcitrance of
Seagrass tissues : implications for long-term carbon sequestration. Frontiers in Plant Science 8(June):1-18. https://doi. org/10.3389/fpls.2017.00925

Twilley RR, Chen R, Hargis T (1992) Carbon sinks in mangroves and their implications to carbon budget of tropical coastal ecosystems. Water, Air, and Soil Pollution 64(1):265-288. https://doi.org/10. 1021/es983796z

Twilley RR, Rovai AS, Riul P (2018) Coastal morphology explains global blue carbon distributions. Frontiers in Ecology and the Environment 16(9):503-508. https://doi.org/10.1002/ fee. 1937

Walton MEM, Al-Maslamani I, Skov MW, Al-Shaikh I, Al-Ansari IS, Kennedy HA, Le Vay L (2014) Outwelling from arid mangrove systems is sustained by inwelling of seagrass productivity. Marine Ecology Progress Series 507:125-137. https://doi.org/10.3354/ meps 10827

Ward ND, Bianchi TS, Medeiros PM, Seidel M, Richey JE, Keil RG, Sawakuchi HO (2017) Where carbon goes when water flows: carbon cycling across the aquatic continuum. Frontiers in Marine Science 4:7. https://doi.org/10.3389/fmars.2017.00007

Wu J (2012) Landscape ecology. In: Leemans R (ed) Ecological systems. Springer, New York. https://doi.org/10.1007/978-1-4614-5755-8 11

Zhang HUI, Teng YUN, Doan TTT, Yat WEIY, Chan SHARN, Kelly BC (2017) Stable nitrogen and carbon isotopes in the sediments and biota from three tropical marine food webs: application to chemical bioaccumulation assessment. Environmental Toxicology and Chemistry 36(9):2521-2532. https://doi.org/10.1002/etc.3796

Zimmer M (2019) Detritus. In: Jorgensen SE, Fath BD (ed). Encyclopedia of Ecology 2nd edition, volume 3. Elsevier: 292-301

\section{Online References}

Meteriological service Singapore, Historical Daily Records visited on 20Aug-2018 http://www.weather.gov.sg/climate-historical-daily/

Tree Functional Attributes and Ecological Database visited 10 Oct 2018 $\mathrm{http}: / /$ worldagroforestry.org

Publisher's Note Springer Nature remains neutral with regard to jurisdictional claims in published maps and institutional affiliations. 